\title{
Customer Satisfaction with Electronic Banking Services in the Saudi Banking Sector
}

\author{
Hani A. AlHaliq ${ }^{1} \&$ Ahmad A. AlMuhirat ${ }^{1}$ \\ ${ }^{1}$ Department of Management Information Systems, College of Business \& Economics, Qassim University, KSA \\ Correspondence: Hani A. AlHaliq, Department of Management Information systems (MIS), College of Business \\ \& Economics (CBE), Qassim University, P.O. Box 6633, Code No.: Buraidah 15452, KSA. Tel: \\ 96-653-710-1272, Ext. 3146. E-mail: hliek@qu.edu.sa/hani.alhaliq@yahoo.com
}

\author{
Received: February 2, 2016 Accepted: March 18, 2016 Online Published: April 19, 2016 \\ doi:10.5539/ass.v12n5p139 URL: http://dx.doi.org/10.5539/ass.v12n5p139
}

\begin{abstract}
This research aims to examine the extent of customer satisfaction with electronic banking (e-banking) services in the Saudi banking sector and to address issues with quality of services by focusing on the following: (i) ease of use; (ii) information security and reliability and its role in influencing customer adoption of electronic services; (iii) the mechanisms of monitoring and control over these services. The research employed analytic and descriptive methodology, collecting primary data through a survey. It examined various aspects of electronic services provided by banks in Saudi Arabia to shed more light on these services and customer expectations, while also taking into account modern studies in this field as secondary data. The results show that Saudi banks have succeeded in attaining significant customer satisfaction by improving their electronic services, facilitating electronic transactions, improving processing performance and enhancing the specifications of electronic services. In addition, they have achieved effective communication with their customers as well as the speed of applications. However, there is an absence of awareness and guidance for customers about the e-banking system. The results of this research lead to some recommendations for improving the electronic services provided by banks in Saudi Arabia to enhance customer satisfaction.
\end{abstract}

Keywords: information technology, information security, e-banking, ease of use, customer satisfaction, adoption, Saudi Arabia

\section{Introduction}

In the last few decades, banks have seen a shift in their objectives and strategies due to the emergence of an information and communications revolution in the financial and banking markets. This has prompted banks to move towards the introduction of a new type of services based on information technology (IT), offering what is known as "electronic banking services", or e-banking, in addition to traditional banking services. There are new concepts and ways of providing services to customers based on IT, including checking customer satisfaction and profitability.

The banking services provided through the Internet are varied, including: a) the dissemination of information of different services and products offered by banks to the public in general and their customers in particular; $b$ ) the possibility of receiving customer inquiries and responding to them through e-mail, as well as providing simple transactions allowing customers to submit their instructions and applications for various services; c) the provision of sites allowing customers to make inquiries about their account balances, undertake financial transactions and pay various bills; d) the opportunity to use various other bank products and deal with the purchase and sale of securities, inter alia.

E-banking has had a significant impact on customers' use of bank services. Electronic services have become the main pillar for Saudi banks because of their ability to improve speed, performance and productivity. Online banking has been fully adopted in the Kingdom of Saudi Arabia as a value-added service to attain customer satisfaction and cost advantages. Banks have also sought to reduce operational costs through the provision of electronic services and gain access to the largest segment of customers in terms of the geographical and temporal dimensions. Moreover, banks have sought greater integration in e-shopping networks. Electronic services provide higher accuracy and reliability in banking service provision due to the low rate of human error, resulting in increased effectiveness and efficiency in the banking business. 
Although the benefits of the adoption of modern technology related to information systems are well known in many areas (administrative, financial, industrial), there are few studies that quantify these benefits scientifically. Thus, this study aims to examine customer satisfaction with e-banking services in the Saudi banking sector and study the reliability and privacy of banking service providers, as well as to address the mechanisms of monitoring and control over these services.

\section{Literature Review and Hypothesis Development}

\subsection{E-Banking}

The term e-banking refers to the provision of small banking products (e.g. current accounts, loans, financial advice) and services (e.g. receipt of deposits, payment of bills, account management, the provision of products and services in exchange for e-money). Chavan (2013) defined e-banking as an Internet portal through which customers can use different types of banking services. It can also be defined as the provision of banking products and services through electronic distribution channels.

The main advantages of e-banking are the time saved through the automated processing of banking services and the provision of adjustment tools to manage customers' money. In addition, Ahmad and Al-Zu'bi (2011) found that e-banking has the following benefits: reducing the costs of accessing and using banking services; increased convenience and time savings, with customers able to conduct transactions 24 hours per day; rapid and continuous access to information; better money management through speeding up the cycle of the transfer of money and increasing the efficiency of business operations.

\subsection{E-Banking in Saudi Arabia}

A report published by the Saudi Ministry of Communications and Information Technology (MCIT, 2015) shows that Saudi Arabia has already started to provide Internet services under certain controls designed to take advantage of the informative aspect of the Internet to provide positive and useful services. According to Al-Somali (2009), Saudi Arabia is a regional leader in e-banking and indeed Saudi Arabia was ranked second in the Middle East in 2015 for the provision of e-banking. Almohaimmeed (2012) noted that Saudi Arabia is one of the countries developing rapidly in many fields, especially in the Internet market. As pointed out by Alotaibi (2015), Saudi Arabia is a financially rich country with well-developed financial services and infrastructure. Thus, the country has succeeded in transferring and adopting technology, including in the financial sector.

According to MCIT (2015), the latest statistics concerning the expansion of the Internet showed that there would be more than three billion Internet users by the end of 2015 , covering $46 \%$ of the world population, estimated at 7.2 million, in the most populated regions. Moreover, the Internet gained approximately 233 million new users in the first half of 2015, an increase of $8 \%$ compared to the number of users in 2013. In 2015, there were nearly 2.8 billion users, comprising approximately $39 \%$ of the world population.

\subsection{Pillars of E-Banking Adoption}

E-banking affects the daily activities of individuals and institutions. For organizations, information is crucial and they cannot operate efficiently without it. Perhaps the best example of the application of IT by organizations is e-banking, which can help organizations achieve their objectives. They have constant access to banking services over the Internet, including electronic payments, safe investments and the exchange of banking information. By exploiting the various advantages e-banking provides, organizations can enhance opportunities for growth and it seems clear that IT can contribute to increasing profits (Ahmadirezaei, 2011).

There are several factors that play a role in e-banking adoption, among which some central pillars are: customer satisfaction, ease of use, trust, information security, competitive advantage, compatibility and knowledge of technology. Each of these is addressed in turn below.

\subsubsection{Customer Satisfaction}

As found by Al-Somali, Gholami, and Clegg (2009), from the customer perspective, a number of aspects influence the adoption of e-banking, including ease of use, education, reliability and resistance to change. On the banking side, Lakhi and Gul (2012) noted that to attract customers and improve their services, banks must invest in IT and promote the culture of e-banking. Thus, banks' objectives are linked to the design of hardware and software necessary to improve access to their e-banking service channels. In particular, banks and other commercial institutions need to develop software applications that are "consumer-friendly" as key aspects of these service channels are that they are easy to use and useful.

Eid (2011) found that the quality of the user interface and the quality of information on e-commerce sites have a positive impact on customer satisfaction. Here, banks need to differentiate themselves as if customers notice 
little, if any, difference in the services provided, any new offer will be held to be the same or similar to those of competitors.

Al-Tit (2015) also found that service quality has a positive influence on customer satisfaction and suggested that this leads to customer retention. Zaim et al. (2010) found that reliability, tangibility and understanding are the key factors in ensuring customer satisfaction, while response and security are also important. Moreover, Mian (2014) found a strong correlation between customer satisfaction and customer loyalty in the banking sector in Saudi Arabia. Loyalty is the "currency of the 21 century" as the cost of providing services to existing clients is five or six times less than that of seeking and serving a new client. Walsh (2005) also found that it is preferable to deal with existing customers rather than having to acquire new customers.

\subsubsection{Ease of Use}

Ease of use refers to the (lack of) effort required to use a particular system, as defined by Davis (1993). Celik (2008) found that the individuals will have a positive view about new technology that they believe is easy to learn and use. In particular, there are strong indications that the ease of use of e-banking services increases the adoption of these services by customers. Thus, the first null hypothesis is:

$\mathrm{HO}_{1}$ : Customers are not satisfied with the ease of use of e-banking services in the Saudi banking sector.

\subsubsection{Reliability}

According to Park and Kim (2003, citing Mayer et al., 1995), trust is the "willingness of a party to be vulnerable to the actions of another party based on the expectation that the other will perform a particular action important to the trustor, regardless of their ability to monitor or control that other party" (p. 712). As noted by Ba and Pavlou (2002), notwithstanding the various advantages of trust, it is extremely difficult to build trust between an institution and a customer in e-commerce, in part because there are many online threats.

Akbar and Parvez (2009) stressed that banks should consider both the present and the future when making decisions concerning appropriate tools for gaining customer confidence. Here, confidence describes the extent of the customer's faith in the bank and suggests the bank's role in giving them the assurances they need about the present and the near future. Customers must have a positive and strong conviction that the bank is working for their benefit as any deficiency in this belief will lead to the client changing banks. Akbar and Parvez (2009) found that $40 \%$ of customers believe that these issues are critical aspects affecting the adoption of e-commerce in Saudi Arabia.

In relation to this, Lakhi and Gul (2012) found that banks need to make improvements to their communication models in order to motivate customers to use e-banking services. In contrast, Eid (2011) found that the quality of the user interface, security and privacy are related to the level of trust on the part of the client, whereas the quality of information is not. Thus, the second hypothesis is as follows:

$\mathrm{HO}_{2}$ : Customers are not satisfied with the trustworthiness of e-banking services in the Saudi banking sector.

\subsubsection{Information Security}

Ambhire and Teltumde (2011) defined information security as the process of protecting the organization and confidence in its systems, as well as maintaining information vital to the enterprise's operations. According to Miyazaki and Fernandez (2001), information security is widely recognized as a crucial by both government and industry organizations. From the consumer's perspective, information security issues can be a barrier to the growth of e-commerce.

Risks with regard to Internet security have been identified as the focus of attention for both experienced users and novices in the use of Internet technologies. Financial and banking institutions protect their own and others' information through the development of security protocols, risk management strategies, application strategies and test execution, monitoring the environment to control risks. Moreover, Al-Jabri and Sohail (2012) noted that banks seek to reduce consumers' perceived risk through the provision of specific guarantees to protect them. In Alqahtani, Al-Badi, and Mayhew's (2012) study of e-commerce consumers in Saudi Arabia, 45.5\% of the respondents agreed that monitoring and control were among the decisive factors influencing the adoption and use of e-commerce. Such issues have driven many Saudi banks to make information security a high priority. Thus, the third hypothesis is as follows:

$\mathrm{HO}_{3}$ : Customers are not satisfied with the information security of e-banking services in the Saudi banking sector.

\subsubsection{Competitive Advantage}

According to Gillard, Bailey, and Nolan (2008), innovation means always being ready to "do something" with 
the willingness to risk defeat and the threat of leakage associated with the adoption of modern technology. This behaviour satisfies the desire of innovators and makes them the first creators to overcome the risks and costs associated with modern technology. As noted by Ezzi (2014), to keep up with recent changes in the markets, banks have to compete with others to attract customers, who in turn seek the best available banking services. In this respect, banks have to be innovators to gain competitive advantage and enhance their own performance against that of their competitors.

\subsubsection{Compatibility}

$\mathrm{Wu}$ and Wang (2005) found that compatibility leads to positive accreditation and noted that human nature drives people to derive satisfaction from behaviours, products and services which are compatible with their lifestyle. In this regard, Al-Jabri and Sohail (2012) found that Saudi Arabia should provide e-banking services that are compatible with customers' previous experiences, lifestyles and beliefs, as well as their current requirements, to meet their expectations and provide optimal support in banking operations.

\subsubsection{Knowledge of Technology}

Davis (1993) found that there is greater user acceptance of e-services among those with knowledge of technology and who believe that the use of technology will enhance productivity. Wang and $\mathrm{Wu}$ (2005) also found this factor to be highly important in determining the use of online banking. In terms of online banking, its rapid adoption relates to the value of the product for technologically aware users keen to benefit from 24-hour availability and the opportunity to accomplish banking tasks for free.

\section{Methodology}

The methodology of the research was developed based on a wide-ranging and in-depth review of the literature. In line with the analytical and descriptive methodology, primary data were collected through a survey and analysed to derive indicators which could be evaluated and interpreted in line with this type of research. To collect the necessary data, a survey was distributed in the AlQassim region of Saudi Arabia. To ensure homogeneity in selection and the accuracy of results, international studies with a close relationship to this research were referred to as secondary source of data.

\subsection{Sampling}

The survey was distributed to 250 customers $(\mathrm{N}=100)$ of the Al Rajhi and Al Ahli banks in the AlQassim region. The response rate was less than $50 \%$, with 100 completed questionnaires returned.

\subsection{Instrument}

The survey was developed based on the works of Al Nahian, Shahriar, and Nayeema (2009), Sadeghi, and Farokhian (2010), Kumbhar (2011), AlKhasawneh, AlSamydai, and Yousif (2012) and Unyathanakorn and Rompho (2014). The survey consisted of 15 items measuring the dimensions ease of use (items 1-5), trust (items 6-10) and information security (items 11-15) on a five-point Likert scale ranging from ( 1 = strongly disagree) to ( $5=$ strongly agree). Before completing the survey, the objectives of the research were clarified and informed consent was obtained from the respondents.

\subsection{Validity}

According to Drost (2011), validity is concerned with the meaningfulness of research components. When researchers measure behaviours, they are concerned about they are measuring what they intend to measure. For this reason, a number of raters specialized in the field were chosen to comment on the questionnaire items and the survey was amended based on their observations.

\subsection{Reliability}

The internal consistency of the survey was calculated using Cronbach's alpha. As shown in Table 1, the coefficient for internal consistency is high and acceptable according to Sakaran (2013).

Table 1. Instrument reliability

\begin{tabular}{cc}
\hline Variables & Cronbach's Alpha \\
\hline Ease of use & 0.64 \\
Information Reliability & 0.75 \\
information security & 0.74 \\
Total & 0.86 \\
\hline
\end{tabular}




\section{Results}

This section addresses the results of the survey and testing of the hypotheses. First, with regard to ease of use, Table 2 shows that customer satisfaction with this aspect of e-banking services in the Saudi banking sector is high (mean $=3.76$; $\mathrm{SD}=0.65$ ). The table also indicates that the response to the question, "How satisfied are you with the organization of e-banking services?" has the highest score (mean $=4.08 ; \mathrm{SD}=0.78$ ), while the response to the question "How satisfied are you with the guidance provided by the e-banking system?" has the lowest score $($ mean $=3.28 ; \mathrm{SD}=1.02)$.

Table 2. Means and standard deviations of the level of customer satisfaction with the ease of use of e-banking services in the Saudi banking sector (in descending order)

\begin{tabular}{ccccc}
\hline & Mean & Std. Deviation & Rank & Level \\
\hline $\mathrm{i}_{1}$ & 4.08 & 0.78 & 1 & high \\
$\mathrm{i}_{3}$ & 3.87 & 0.95 & 2 & high \\
$\mathrm{i}_{2}$ & 3.81 & 0.99 & 3 & high \\
$\mathrm{i}_{4}$ & 3.77 & 0.87 & 4 & high \\
$\mathrm{i}_{5}$ & 3.28 & 1.02 & 5 & Medium \\
Total & 3.76 & 0.65 & - & High \\
\hline
\end{tabular}

Table 3 shows that customer satisfaction in relation to trust in e-banking services in the Saudi banking sector is high (mean $=3.76 ; \mathrm{SD}=0.70$ ). The table also indicates that the response to the question "How satisfied are you with electronic bank account statements and reports?" has the highest score (mean $=4.16$; $\mathrm{SD}=0.80$ ), while the response to the question "How satisfied are you with the speed and efficiency of e-banking in solving problems?" has the lowest score $($ mean $=3.30 ; \mathrm{SD}=1.20)$.

Table 3. Means and standard deviations of the level of customer satisfaction with trust in e-banking services in the Saudi banking sector (in descending order)

\begin{tabular}{ccccc}
\hline & Mean & Std. Deviation & Rank & Level \\
\hline $\mathrm{i}_{6}$ & 4.16 & 0.80 & 1 & high \\
$\mathrm{i}_{9}$ & 4.16 & 0.98 & 2 & high \\
$\mathrm{i}_{8}$ & 3.69 & 0.97 & 3 & high \\
$\mathrm{i}_{10}$ & 3.50 & 1.20 & 4 & Medium \\
$\mathrm{i}_{7}$ & 3.30 & 1.20 & 5 & Medium \\
Total & 3.76 & 0.70 & - & High \\
\hline
\end{tabular}

Table 4 shows that customer satisfaction with the information security of e-banking services in the Saudi banking sector is high (mean $=4.05 ; \mathrm{SD}=0.59$ ). The table also indicates that the response to the question "How satisfied are you with the security of electronic bank account statements and reports?" has the highest score (mean $=4.16 ; \mathrm{SD}=0.80$ ), while the response to the question "How satisfied are you with the speed and efficiency of e-banking in solving problems?" has the lowest score (mean $=3.30 ; \mathrm{SD}=1.20$ ).

Table 4. Means and standard deviations of the level of customer satisfaction with the information security of e-banking services in the Saudi banking sector (in descending order)

\begin{tabular}{ccccc}
\hline & Mean & Std. Deviation & Rank & Level \\
\hline $\mathrm{i}_{15}$ & 4.34 & 0.80 & 1 & High \\
$\mathrm{i}_{12}$ & 4.11 & 0.91 & 2 & High \\
$\mathrm{i}_{13}$ & 4.08 & 0.93 & 3 & High \\
$\mathrm{i}_{11}$ & 3.89 & 0.98 & 4 & Medium \\
$\mathrm{i}_{14}$ & 3.84 & 0.95 & 5 & Medium \\
Total & 4.05 & 0.59 & - & High \\
\hline
\end{tabular}


The research hypotheses were tested using the $t$-test for each variable. Table 5 shows that the $t$-value calculated for the first variable was 9.33 with a $p$-value of 0.00 , which is lower than the acceptable level of significance $(\alpha=0.05)$. Therefore the alternate hypothesis is accepted, meaning that customers are satisfied with the ease of use of e-banking services in the Saudi banking sector.

For the second variable, the $t$-value was 8.71 with a $p$-value of 0.00 , again lower than the acceptable level of significance $(\alpha=0.05)$. Therefore, the alternate hypothesis that customers are satisfied with the trustworthiness of e-banking services in the Saudi banking sector is accepted.

Finally, the results show a $t$-value for the third variable of 14.36 with a $p$-value of 0.00 , below the acceptable level of significance $(\alpha=0.05)$. Thus, the alternate hypothesis that customers are satisfied with the information security of e-banking services in the Saudi banking sector is accepted.

Table 5. Results of hypothesis testing using the $t$-test

\begin{tabular}{ccccccc}
\hline Hypothesis & Mean & Std. Deviation & $\mathrm{t}$ & Sig. (2-tailed) & Mean Difference & Result \\
\hline $\mathrm{H}_{1}$ & 3.76 & 0.65 & 9.33 & 0.00 & 0.76 & Accepted \\
$\mathrm{H}_{2}$ & 3.76 & 0.70 & 8.71 & 0.00 & 0.76 & Accepted \\
$\mathrm{H}_{3}$ & 4.05 & 0.59 & 14.36 & 0.00 & 1.05 & Accepted \\
Total & 3.86 & 0.55 & 12.55 & 0.00 & 0.86 & Accepted \\
\hline
\end{tabular}

\section{Conclusion}

The results show that Saudi e-banking does not pay adequate attention to the guidance provided to customers concerning how to deal with their websites, as mentioned by many researchers (e.g. Ismail and Osman, 2012). These authors identified 11 factors that affect the adoption of e-banking, including a weak role on the part of banks in raising client awareness and lack of clarity concerning e-banking guidelines and instructions. Shahar (2002) noted that complexity is the most important problem in e-banking systems. Moreover, Yoon and Occeña (2014) argued that lack of adequate guidance on the implementation of e-banking systems has proved to be a challenge that is difficult to overcome. The greatest emphasis has been placed on the organization and improvement of electronic services, facilitating electronic transactions, processing performance and enhancing the specifications of electronic services.

The results also showed that Saudi e-banking should pay greater attention to the issue of stimulating customers to opt for electronic services, in addition to the need for banks to develop the speed and efficiency of electronic solutions to problems. Folake (2014) found that to increase customers' acceptance of e-banking, banks need to understand the antecedents of trust and develop sound strategies to build customers' trust in internet banking.

However, the results also show that Saudi e-banking has succeeded - from a customer perspective - in attaining significant satisfaction through effective communication using reports and notices about daily account operations, as well as ensuring the speed of electronic applications. While e-banking has paid considerable attention to the confidentiality of customers' personal information, in addition to the confidentiality and privacy of electronic services, it has ignored the issue of customer awareness of the importance of confidentiality and privacy of their personal data. As Alsomali (2015) argued, e-banks must provide user guides for consumers which they can consult to use online banking safely.

The results of this research show that Saudi banks have broadly attained customer satisfaction, but they also highlight areas in which Saudi banks must improve their e-banking services to attain customer satisfaction and achieve greater success.

\section{Limitations and Future Research}

There are many limitations in this research. First, the sample was too small to confer reliability or generalizability in the findings. Second, the respondents were familiar with dealing with online applications, based on their level of education. Third, the sample was concentrated in the AlQassim region only. Fourth, the period of study was limited.

In future research, the study of e-banking could be expanded to include all regions of the Kingdom of Saudi Arabia, which would provide a more homogeneous sample. A larger sample size covering a wider geographical area will provide more reliable and accurate results. Indeed, such research might be undertaken in other countries 
with very different provision of services and consumers. Moreover, future research could encompass a greater diversity of knowledge and culture, in particular focusing on different age groups. Finally, studies of online services could investigate different business areas, focusing on new business requirements.

\section{References}

Ahmad, A., \& Al-Zu'bi, H. (2011). E-banking Functionality and Outcomes of Customer Satisfaction: An Empirical Investigation. International Journal of Marketing Studies, 3(1), 50-65.

Ahmadirezaei, H. (2011). The Effect of Information Technology in Saderat Banking System. Procedia - Social and Behavioral Sciences, 30, 13-16. http://dx.doi.org/10.1016/j.sbspro.2011.10.005

Akbar, M. M., \& Parvez, N. (2009). Impact of Service Quality, Trust, and Customer satisfaction on Customer Loyalty. ABAC Journal, 29(1), 24-38.

Al Nahian, R., Md. Shahriar, A., \& Nayeema. I. (2009). The Adoption of E-banking in Developing Countries: A Theoretical Model for SMEs. International Review of Business Research Papers, 5(6), 212-230.

Al-Jabri, I. M., \& Sohail, M. S. (2012). Mobile Banking Adoption: Application of Diffusion of Innovation Theory. Journal of Electronic Commerce Research, 13(4), 379-391.

AlKhasawneh, M. H., AlSamydai, M. J., \& Yousif, R. O. (2012). The factors influencing consumers' satisfaction and continuity to deal with E-Banking services in Jordan. Global Journals Inc., 12(14), 1-15.

Almohaimmeed, B. M. (2012). Customer Behaviour towards Internet Banking: A Study of the Dormant Users of Saudi Arabia (Unpublished $\mathrm{PhD}$ thesis). The University of Birmingham.

Alotaibi, M. N. (2015). The IT infrastructure and e-banking facilities in Saudi banking system environment. International Journal of Economics, Commerce and Management, 3(4), 1-18.

Alqahtani, M. A., Al-Badi A. H., \& Mayhew P. J. (2012). The Enablers and Disablers of E-Commerce: Consumers' Perspectives. EJISDC, 54(1), 1-25.

Al-Somali, S. A., Gholami, R., \& Clegg, B. (2009). An investigation into the acceptance of online banking in Saudi Arabia. Operations \& Information Management Group, Technovation, 29, 130-141. http://dx.doi.org/10.1016/j.technovation.2008.07.004

Alsomali, Z. (2015). Facilitating adoption of e-banking in Saudi Arabia through reduction of perceived risk in e-banking (Unpublished $\mathrm{PhD}$ thesis). Brunel University London.

Al-Tit, A. A. (2015). The Effect of Service and Food Quality on Customer Satisfaction and Hence Customer Retention. Asian Social Scence, 11(23), 129-139. http://dx.doi.org/10.5539/ass.v11n23p129

Ambhire, V., \& Teltumde, P. (2011). Information Security in Banking and Financial Industry. International Journal of Computational Engineering \& Management, 14.

Ba, S., \& Pavlou, P. A. (2002). Evidence of the effect of trust building technology in electronic markets: price premiums and buyer behavior. MIS Quarterly, 26(3), 243-268. http://dx.doi.org/10.2307/4132332

Celik, H. (2008). What determines Turkish customers' acceptance of internet banking. International Journal of Bank Marketing, 26(5), 353-370. http://dx.doi.org/10.1108/02652320810894406

Chandler, D., \& Munday, R. (2012). Information technology. A Dictionary of Media and Communication. Oxford University Press. http://dx.doi.org/10.1093/acref/9780199568758.001.0001

Chavan J. (2013). Online banking - the advantages and challenges in the emerging economy. International Journal of Research in Business Management, 1(1), 19-26.

Chung, N., \& Kwon, S. J. (2009). The Effects of Customers' Mobile Experience and Technical Support on the Intention to Use Mobile Banking. Cyber Psychology \& Behaviour, 12(5), 539-543. http://dx.doi.org/10.1089/cpb.2009.0014

Davis, F. D. (1993). User acceptance of information technology: system characteristics, user perception and behavioral impact. International journal of Man-machine studies, 38, 475-487. http://dx.doi.org/10.1006/ imms.1993.1022

Drost, E. A. (2011). Validity and Reliability in Social Science Research. Education Research and Perspectives journal, 38(1), 105-123.

Eid, M. I. (2011). Determinants of E-Commerce Customer Satisfaction, Trust, and Loyalty in Saudi Arabia. Journal of Electronic Commerce Research, 12(1), 78-93. 
Ezzi, S. W. (2014). A theoretical Model for Internet banking: beyond perceived usefulness and ease of use. Archives of Business Research, 2(2), 31-46. http://dx.doi.org/10.14738/abr.22.184

Folake, N. P. (2014). The Impact of Trust Antecedents in Acceptance of Internet Banking in Nigeria. International Journal of Economic and Business Management, 2(2), 19-24.

Gillard, S., Bailey, D., \& Nolan, E. (2008). Ten Reasons for IT Educators to be Early Adopters of IT Innovations. Informing Science Institute, 7(1), 21-33.

Ismail, M. A., \& Osman, M. A. (2012, December). Factors Influencing the Adoption of E-banking in Sudan: Perceptions of Retail Banking Clients. Journal of Internet Banking and Commerce, 17(3), 1-16.

Kumbhar, V. M. (2011). Factors affecting the customer satisfaction in e-banking: some Evidences form Indian banks. Management Research and Practice, 3(4), 1-14.

Lakhi, M., \& Gul, R. (2012). Factors Distressing Internet Banking Adoption among Adult Students: Evidence from Kingdom of Saudi Arabia. Business and Management Review, 2(1), 76-82.

Mian, T. S. (2014). The Role of Service Quality in Developing Customer Loyalty in the Banking Sector: A Case study of the Kingdom of Saudi Arabia. International Journal of Accounting and Financial Reporting, 4(2), 339-360. http://dx.doi.org/10.5296/ijafr.v4i2.6488

Miyazaki, A. D., \& Fernandez, A. (2001). Consumer Perceptions of Privacy and Security Risks for Online Shopping. Journal of Consumer Affairs, 35(1), 27-44. http://dx.doi.org/10.1111/j.1745-6606.2001.tb00101.x

Rogers, E. M., Medina, U. E., Rivera, M. A., \& Wiley, C. J. (2005). Complex adaptive systems and the diffusion of innovations. The Innovation Journal: The Public Sector Innovation Journal, 10(3), 1-26.

Sadeghi, T., \& Farokhian, S. (2010). Electronic Banking Acceptance Model (EBAM) in Iran. World Applied Sciences Journal, 11(5), 513-525.

Sekaran, U., \& Bougie R. (2013). Research Methods for Business: A Skill-Building Approach (6th ed.). John Wiley \& Sons, Inc.

Unyathanakorn, K., \& Rompho, N. (2014). Factors Affecting Customer Satisfaction in Online Banking Service. Journal of Marketing Development and Competitiveness, 8(2), 1-11.

Wu, J. H., \& Wang, S. C. (2005). What drives mobile commerce? An empirical evaluation of the revised technology acceptance model. Information and Management, 42, 719-729. http://dx.doi.org/10.1016/j.im. 2004.07.001

\section{Copyrights}

Copyright for this article is retained by the author(s), with first publication rights granted to the journal.

This is an open-access article distributed under the terms and conditions of the Creative Commons Attribution license (http://creativecommons.org/licenses/by/3.0/). 